\section{Sheep milk yogurt from a short food supply chain: study of the microbiological, chemico-physical and organoleptic parameters in relation to shelf-life}

\author{
Nicla Marri, Virginia Carfora, \\ Daniela Patriarca, \\ Maria Cristina Veschetti, \\ Giuseppina Giacinti, Gilberto Giangolini, \\ Simonetta Amatiste
}

Centro di Referenza Nazionale per la qualità del latte e dei derivati ovini e caprini, Istituto Zooprofilattico Sperimentale delle Regioni Lazio e Toscana, Roma, Italy

\section{Abstract}

Aim of this work was to analyse some microbiological, chemico-physical and organoleptic parameters of sheep milk yogurt during and after its declared shelf-life. Five samples of a sheep's milk yogurt of the same lot, collected from a short supply chain ovine dairy farm of the Roman province, were analysed. Declared shelf-life of the product was 30 days. The products were examined at $2,14,30,35$ and 40 days from the production date, performing the following microbiological analyses: enumeration of i) colony-forming units characteristic of the yogurt, ii) Enterobacteriaceae, iii) yeasts and/or moulds at $25^{\circ} \mathrm{C}$. Microbiological identification was performed by miniature biochemical tests and for the lactic acid bacteria also by PCR. At every test interval, evaluation of organoleptic parameters and $\mathrm{pH}$ was also performed. The analysed product maintained an almost constant amount of lactic acid bacteria until the end of the declared shelf-life. Concerning lactic acid bacteria, a 100\% concordance of the results observed by using biochemical identification methods and PCR assays was obtained. After 14 days from the production, the presence of yeasts (Candida famata) was revealed, while the presence of moulds was detected after 30 days. Ralstonia picketii, an environmental microorganism, was also isolated. The results obtained in this study indicate that yogurt spoilage is mainly due to the growth of specific microorganisms of spoilage, such as yeasts and moulds.

\section{Introduction}

Yogurt is a fermented milk product widely known and appreciated for its beneficial effects on consumers health. To obtain a firstrate yogurt, excellent quality raw materials and production techniques that follow the good manufacturing practices should be used. Yogurt is a perishable food due to its composition and physico-chemical properties. Its shelflife could be established based on microbiological data and the use of other parameters such as sensory analysis, aw, $\mathrm{pH}$ and titratable acidity (Mataragas et al., 2011).

Chemico-physical and microbiological modifications of yogurt until the expiry date, which can vary from 20 to 40 days from the date of production, can cause undesired changes in the organoleptic properties of the product (colour, odour, flavour and texture). For this reason, correct storage conditions until the end of shelf life is essential for the maintenance of product characteristics. The alteration of dairy products such as yogurt is mainly linked to the development of specific spoilage organisms (SSOs) such as yeasts and moulds. The deterioration of yogurt by yeasts is generally identified by the development of abnormal flavours, yeast odour and $\mathrm{CO}_{2}$ production with consequent swelling of the lid heat-sealed when used (Vallone et al., 2001). In absence of specific guidelines in the Italian legislation, some Authors report that yogurt cultures (Lactobacillus delbrueckii subsp. bulgaricus and Streptococcus thermophilus bacteria) should be alive and viable until the time of consumption and in quantities not less than $10^{6}$ CFU/g (Health Ministry, 1972).

The decrease in $\mathrm{pH}$ caused by the production of lactic acid is one of the desirable effects of the metabolic activity of lactic acid bacteria. In fact, the main benefits of yogurt are related to its acidity: the production of lactic acid from lactose can allow the consumption of this product also by lactose intolerant consumers; moreover, it promotes the absorption of calcium and minerals (Al-Kadamany et al., 2002; Mataragas et al., 2011). The analysis of the aspects described above is essential to determine the conditions of conservation and define the length of shelf-life period of yogurt.

The aim of this work was to analyse some microbiological, chemico-physical and organoleptic parameters in samples of sheep milk yogurt produced in a short supply chain farm, during the shelf-life declared by the dairy farmer.

\section{Materials and Methods}

Five samples of a sheep milk yogurt of the same lot, collected from a short supply chain ovine dairy farm of the Roman province, were analysed. Declared shelf-life of the product was 30 days. The yogurts stored at $4^{\circ} \mathrm{C}$ were exam-
Correspondence: Simonetta Amatiste, Centro di Referenza Nazionale per la qualità del latte e dei derivati ovini e caprini, Istituto Zooprofilattico Sperimentale delle Regioni Lazio e Toscana, via Appia Nuova 1411, 00178 Roma, Italy.

Tel. +39.067.9099313 - Fax: +39.067.9099406.

E-mail: simonetta.amatiste@izslt.it

Key words: Yogurt, Sheep milk, Shelf-life, Lactic acid bacteria, Specific spoilage organisms.

Conflict of interests: the authors declare no potential conflict of interests.

Received for publication: 12 May 2013

Revision received: 28 January 2014.

Accepted for publication: 28 January 2014.

This work is licensed under a Creative Commons Attribution 3.0 License (by-nc 3.0).

(C) Copyright N. Marri et al., 2014

Licensee PAGEPress, Italy

Italian Journal of Food Safety 2014; 3:1695

doi:10.4081/ijfs.2014.1695

ined in 5 sessions of analysis: at 2, 14, 30, 35 and 40 days from the production date.

The following microbiological analysis were performed: enumeration of characteristic microorganisms of yogurt (ISO 7889:2003; ISO, 2003a), identification of Lactobacillus delbrueckii bulgaricus and Streptococcus thermophilus (ISO 9232:2003; ISO, 2003b), enumeration of Enterobacteriaceae (ISO 21528-2: 2004; ISO, 2004a), enumeration of yeasts and moulds at $25^{\circ} \mathrm{C}$ (ISO 6611:2004; ISO, 2004b).

The identification of the isolated microorganisms was performed using miniaturised biochemical tests (API CHL Biomerieux ${ }^{\circledR}$, API C AUX Biomerieux ${ }^{\circledR}$ and API NE Biomerieux ${ }^{\circledR}$; bioMérieux, Marcy l'Etoile, France). The identity of lactic acid bacteria was also verified by PCR analysis. DNA was extracted from bacterial colonies by using boiling method and subjected to PCR using primers and reaction conditions reported in the literature for the identification of Streptococcus thermophilus (Fortina et al., 2003), Lactobacillus delbrueckii subsp. bulgaricus and subsp. lactis (Torriani et al., 1999), and a GeneAmp ${ }^{\circledR}$ PCR System 9700 (Applied Biosystems, Carlsbad, CA, USA) machine.

Amplified products were visualised on 1.2\% agarose gel containing Gel Red $^{\circledR}$ in Trisacetate-EDTA $1 \mathrm{X}$ by using a UV-transilluminator. In each analysis session, the organoleptic acceptability of each sample was evaluated by criteria such as discolouration, mould formation, off-odours, abnormal flavours and texture. The $\mathrm{pH}$ of each sample was measured with a MP225 pH meter (Mettler Toledo Inc., Leicester, UK) with a probe for the detection of the temperature and electrode combined as 
ale (UFC /g) aLb (UFC/g) QY(UFC/g) aM (UFC/g)

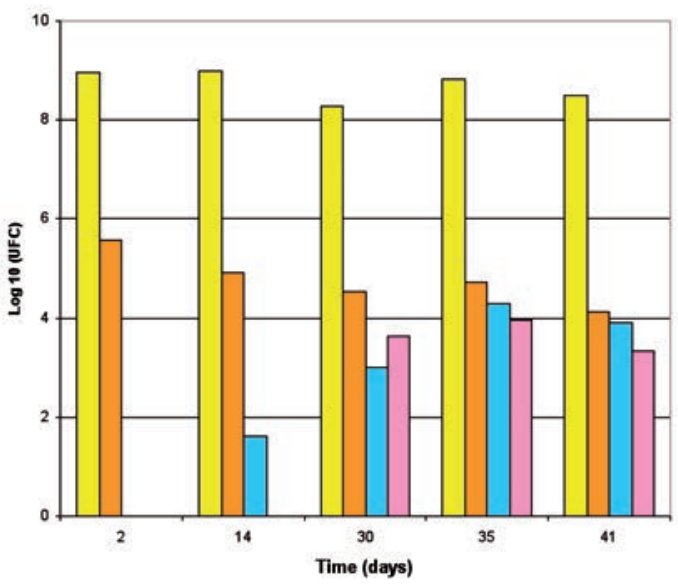

Figure 1. Sheep milk yogurt storage test at $4^{\circ} \mathrm{C}$ : lactic acid streptococci $(\mathrm{Lc})$, lactobacilli $(\mathrm{Lb})$, yeasts $(\mathrm{Y})$ and moulds $(\mathrm{M})$ concentrations $(\mathrm{CFU} / \mathrm{g})$.

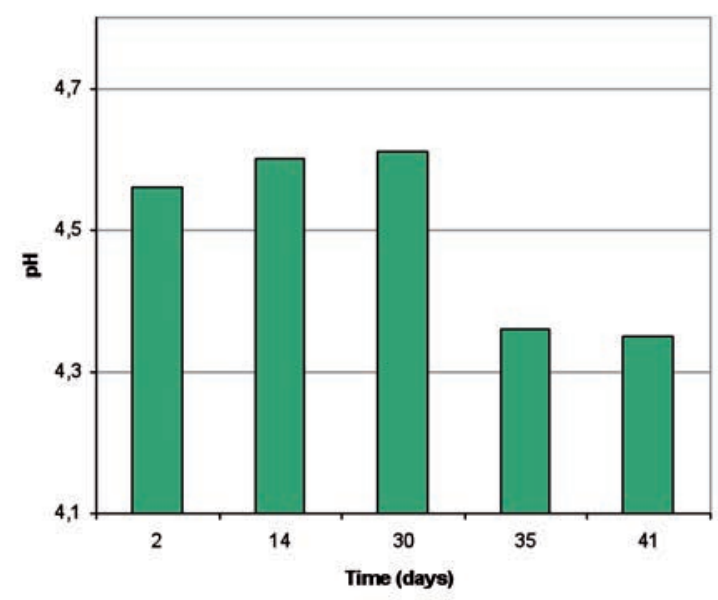

Figure 2. Evolution of $\mathrm{pH}$ during sheep milk yogurt storage test at $4^{\circ} \mathrm{C}$. follows: once the sample reached $25^{\circ} \mathrm{C}$, the determination of $\mathrm{pH}$ was performed repeating the measurements in duplicate for each sample. The same analyses were also performed on a single sample of bulk milk collected from the same farm.

\section{Results}

The analysed product maintained an almost constant amount of lactic acid streptococci (on the order of $10^{8} \mathrm{CFU} / \mathrm{g}$ ) until the end of the declared shelf-life (Figure 1). The concentration of lactobacilli remained almost constant until the end of shelf-life (with a concentration on the order of $10^{5} \mathrm{CFU} / \mathrm{g}$ ), followed by a slight decrease after the expiry date (Figure 1).

Concerning lactic acid bacteria, on the totality of the bacterial strains identified as Lactobacillus delbrueckii subsp. bulgaricus and Streptococcus thermophilus, there was a $100 \%$ concordance of results by using biochemical and PCR methods. The concentration of enterobacteria was found to be $<10 \mathrm{CFU} / \mathrm{g}$ in all samples. The presence of yeasts was detected starting from 14 days after production, with a concentration of $40 \mathrm{CFU} / \mathrm{g}$; during the subsequent analyses they increased, until a concentration of $10^{3} \mathrm{CFU} / \mathrm{g}$ at the end of the shelf-life. The result of the yeast typing on the isolates revealed the presence of Candida famata species only. The presence of moulds was observed starting from 30 days of production (expiry date of the product) at a concentration of $4.3 \times 10^{3} \mathrm{CFU} / \mathrm{g}$. Overall, the microbiological analyses performed during the shelf-life period revealed a modest increase of undesirable microorganisms such as yeasts and moulds, with a constant concentration or a slight decrease in lactic acid bacteria. From the examined yogurts and from the bulk milk sample as well, the presence of Ralstonia picketii, i.e. a contaminating microorganism probably of environmental origin, was detected.

The organoleptic characteristics of the products remained unchanged until the end of the declared shelf-life. Therefore, the presence of yeasts and moulds produced no substantial organoleptic variations up to 30 days from the production date. However, a bitter/cheese flavour and an acrid smell was perceived in the yogurts after the expiry date of the product.

The $\mathrm{pH}$ values measured from the examined yogurts showed minimal variations until the end of the shelf-life (from 4.56 to 4.61), while a decrease (until 4.35) occurred after the end of shelf-life (Figure 2).

\section{Discussion}

As reported in the literature, our results showed that the process of deterioration in yogurt is due primarily to the development of $\mathrm{SSOs,} \mathrm{such} \mathrm{as} \mathrm{yeasts} \mathrm{and} \mathrm{moulds;} \mathrm{these} \mathrm{organ-}$ isms are able to ferment lactose and sucrose also at refrigeration temperatures and low $\mathrm{pH}$ values. The presence of these organisms can be determined by: addiction of characterising ingredients, such as cereals, fruit not properly pasteurised; application of improper production and/or storage practices; use of inadequate raw materials. In this case, it is important to evaluate the starting microbiological quality of the milk (Mataragas et al., 2011).
Only in very few cases the source of contamination of yogurt are the starter cultures; thus, a correct monitoring of the production and storage areas of the products is pivotal.

\section{Conclusions}

Research to identify the origin of the contamination by Ralstonia picketii are still ongoing. Good sensory characteristics and an almost constant concentration of lactic acid bacteria were maintained during all the commercial life of the products. However, the study of contaminating microorganisms detected could be of a certain relevance. Predictive models might be useful to study the process of deterioration of yogurts by contaminants. Such information could be extremely relevant for dairy farmers to determine a suitable shelf-life of their products (Al-Kadamany et al., 2002; Mataragas et al., 2011; Sofu and Evinci, 2007). In order to evaluate meaningfully chemicalphysical and microbiological modifications during the shelf-life period of this product, it could be helpful to extend the number of samples.

\section{References}

Al-Kadamany E, Toufeili I, Khattar M, AbouJawdeh Y, Harakeh S, Haddad T, 2002. Determination of shelf life of concentrated yogurt (labneh) produced by in-bag straining of set yogurt using hazard analysis. J Dairy Sci 85:1023-30. 
Fortina GM, Ricci G, Acquati A, Zeppa G, Gandini A, Manichini PL, 2003. Genetic characterization of some lactic acid bacteria occuring in an artisanal protected denomination origin (PD0) Italian cheese, the Toma piemontese. Food Microbiol 20:397-404.

Health Ministry, 1972. Circular of January 4, 1972, n.2. Production and trade of yogurt. Italian Health Ministry Publ., Rome, Italy.

ISO, 2003a. Yogurt. Enumeration of characteristic microorganisms. Colony-count technique at 37 degrees ${ }^{\circ} \mathrm{C}$. ISO Norm 7889:2003 IDF 117:2003. International Standardization Organization ed., Geneva, Switzerland.

ISO, 2003b. Yogurt. Identification of characteristic microorganisms (Lactobacillus del- brueckii subsp. bulgaricus and Streptococcus thermophilus). ISO Norm 9232:2003 IDF 146:2003. International Standardization Organization ed., Geneva, Switzerland.

ISO, 2004a. Microbiology of food and animal feeding stuffs. Horizontal methods for the detection and enumeration of Enterobacteriaceae. Part 2: colony-count method. ISO Norm 21528-2:2004. International Standardization Organization ed., Geneva, Switzerland.

ISO, 2004b. Milk and milk products. Enumeration of colony-forming units of yeasts and/or moulds. Colony-count technique at 25 degrees ${ }^{\circ} \mathrm{C}$. ISO Norm 6611:2004 IDF 94:2004. International Standardization Organization ed., Geneva,
Switzerland.

Mataragas M, Dimitriou V, Skandamis PN, Drosinos EH, 2011. Quantifying the spoilage and shelf-life of yogurt with fruits. Food Microbiol 28:611-6.

Sofu A, Ekinci FY, 2007. Estimation of storage time of yogurt with artificial neural network modeling. J Dairy Sci 90:3118-25.

Torriani S, Zapparoli G, Dellaglio F, 1999. Use of PCR-based methods for rapid differentiation of Lactobacillus delbrueckii subsp. bulgaricus and L. delbrueckii subsp. lactis. Appl Environ Microb 65:4351-6.

Vallone C, Cantoni C, Cocolin L, Comi G, 2001. Lieviti ed alterazioni di yogurt alla frutta. Ind Aliment 40:1001-6. 